\title{
Front Matter: Volume 8279
}

, "Front Matter: Volume 8279," Proc. SPIE 8279, Emerging Liquid Crystal Technologies VII, 827901 (21 February 2012); doi: 10.1117/12.927874

SPIE. Event: SPIE OPTO, 2012, San Francisco, California, United States 


\section{PROCEEDINGS OF SPIE}

\section{Emerging Liquid Crystal Technologies VII}

\section{Liang-Chy Chien}

Editor

22-25 January 2012

San Francisco, California, United States

Sponsored and Published by

SPIE 
The papers included in this volume were part of the technical conference cited on the cover and title page. Papers were selected and subject to review by the editors and conference program committee. Some conference presentations may not be available for publication. The papers published in these proceedings reflect the work and thoughts of the authors and are published herein as submitted. The publisher is not responsible for the validity of the information or for any outcomes resulting from reliance thereon.

Please use the following format to cite material from this book:

Author(s), "Title of Paper," in Emerging Liquid Crystal Technologies VII, edited by Liang-Chy Chien, Proceedings of SPIE Vol. 8279 (SPIE, Bellingham, WA, 2012) Article CID Number.

ISSN 0277-786X

ISBN 9780819489227

Published by

SPIE

P.O. Box 10, Bellingham, Washington 98227-0010 USA

Telephone +1 3606763290 (Pacific Time) · Fax +1 3606471445

SPIE.org

Copyright () 2012, Society of Photo-Optical Instrumentation Engineers

Copying of material in this book for internal or personal use, or for the internal or personal use of specific clients, beyond the fair use provisions granted by the U.S. Copyright Law is authorized by SPIE subject to payment of copying fees. The Transactional Reporting Service base fee for this volume is $\$ 18.00$ per article (or portion thereof), which should be paid directly to the Copyright Clearance Center (CCC), 222 Rosewood Drive, Danvers, MA 01923. Payment may also be made electronically through CCC Online at copyright.com. Other copying for republication, resale, advertising or promotion, or any form of systematic or multiple reproduction of any material in this book is prohibited except with permission in writing from the publisher. The CCC fee code is 0277-786X/12/\$18.00.

Printed in the United States of America.

Publication of record for individual papers is online in the SPIE Digital Library.

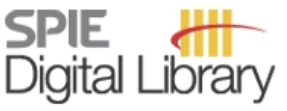

SPIEDigitalLibrary.org

Paper Numbering: Proceedings of SPIE follow an e-First publication model, with papers published first online and then in print and on CD-ROM. Papers are published as they are submitted and meet publication criteria. A unique, consistent, permanent citation identifier (CID) number is assigned to each article at the time of the first publication. Utilization of CIDs allows articles to be fully citable as soon as they are published online, and connects the same identifier to all online, print, and electronic versions of the publication. SPIE uses a six-digit CID article numbering system in which:

- The first four digits correspond to the SPIE volume number.

- The last two digits indicate publication order within the volume using a Base 36 numbering system employing both numerals and letters. These two-number sets start with 00, 01, 02, 03, 04 , $05,06,07,08,09,0 A, 0 B \ldots$. OZ, followed by 10-1Z, 20-2Z, etc.

The CID number appears on each page of the manuscript. The complete citation is used on the first page, and an abbreviated version on subsequent pages. Numbers in the index correspond to the last two digits of the six-digit CID number. 


\section{Contents}

vii Conference Committee

\section{NEW MATERIALS AND EFFECTS}

827903 Pre-organized liquid crystals: biaxial nature of laterally-connected dimer (Invited Paper) [8279-02]

I. Nishiyama, DIC Corp. (Japan); Y. Tabe, Waseda Univ. (Japan); J. Yamamoto, Y. Takanishi,

Y. Ishii, Kyoto Univ. (Japan); H. Yokoyama, Kent State Univ. (United States)

\section{PHOTONIC CRYSTALS}

827907 Natural photonic crystals: formation, structure, function (Invited Paper) [8279-06] M. H. Bartl, M. R. Dahlby, The Univ. of Utah (United States); F. P. Barrows, The Univ. of Utah (United States) and Univ. of Virginia (United States); Z. J. Richens, T. Terooatea, M. R. Jorgensen, The Univ. of Utah (United States)

827909 Preparation of porous polymer materials for bulky liquid crystal devices (Invited Paper) [8279-08]

T. Nose, T. Ito, Akita Prefectural Univ. (Japan); T. Watanabe, K. Ito, S. Yanagihara, Yurikogyo Co., Ltd. (Japan); R. Ito, M. Honma, Akita Prefectural Univ. (Japan)

\section{LASERS}

8279 OB Electrically and all-optically controllable random lasers based on dye-doped liquid crystal films (Invited Paper) [8279-10]

C.-R. Lee, J.-D. Lin, B.-Y. Huang, National Cheng Kung Univ. (Taiwan)

\section{POLARIZERS AND SPATIAL LIGHT MODULATORS}

8279 OD Thin film polarizer based on photo-curable chromonic liquid crystalline solutions (Invited Paper) [8279-12]

H.-J. Yang, S. Yoon, Y.-J. Bae, Chonbuk National Univ. (Korea, Republic of); S.-H. Shin, Korea Institute of Industrial Technology (Korea, Republic of); K.-U. Jeong, M.-H. Lee, Chonbuk National Univ. (Korea, Republic of)

8279 OE Multi-twist retarders for broadband polarization transformation [8279-13]

R. K. Komanduri, J. Kim, K. F. Lawler, M. J. Escuti, North Carolina State Univ. (United States) 
8279 OG Binary systems of discotic liquid crystalline semiconductors toward solution-processing thin film devices (Invited Paper) [8279-15]

Y. Shimizu, National Institute of Advanced Industrial Science and Technology (Japan); Y. Matsuda, National Institute of Advanced Industrial Science and Technology (Japan) and Ryukoku Univ. (Japan); F. Nekelson, Y. Miyake, National Institute of Advanced Industrial Science and Technology (Japan) and Osaka Univ. (Japan); H. Yoshida, A. Fujii, M. Ozaki, Ryukoku Univ. (Japan)

$8279 \mathrm{OH}$ Directed assembly and in situ manipulation of semiconductor quantum dots in liquid crystal matrices (Invited Paper) [8279-16]

A. L. Rodarte, C. G. L. Ferri, C. Gray, L. S. Hirst, S. Ghosh, Univ. of California, Merced (United States)

\section{TUNABLE FILTERS}

8279 Ol Characterization and applications of liquid crystals in the THz frequency range (Invited Paper) [8279-17]

C.-L. Pan, National Tsing Hua Univ. (Taiwan); R.-P. Pan, National Chiao Tung Univ. (Taiwan)

8279 0J Magnetically tunable metallic photonic crystals immersed in liquid crystal for terahertz wave (Invited Paper) [8279-18]

R.-P. Pan, C.-C. Shih, T.-T. Tang, Y.-G. Wang, H.-Y. Wu, C.-J. Lin, National Chiao Tung Univ. (Taiwan); C.-L. Pan, National Tsing Hua Univ. (Taiwan)

8279 OL Observation of PDLCs by SHG laser scanning microscopy using a liquid crystal vector beam generator [8279-20]

A. Tanabe, M. Kurihara, Y. Saito, N. Hashimoto, Citizen Holdings Co. Ltd. (Japan); Y. Kozawa, S. Sato, Tohoku Univ. (Japan) and JST CREST (Japan); T. Hibi, T. Nemoto, Hokkaido Univ. (Japan) and JST CREST (Japan)

\section{ACTUATORS AND SENSORS}

8279 OM Towards micrometer sized core-shell actuators from liquid crystalline elastomers by a continuous flow synthesis (Invited Paper) [8279-21]

E.-K. Fleischmann, H.-L. Liang, Johannes Gutenberg-Univ. Mainz (Germany); J. Lagerwall, Seoul National Univ. (Korea, Republic of); R. Zentel, Johannes Gutenberg-Univ. Mainz (Germany)

8279 ON Switchable and responsive liquid crystal-functionalized microfibers produced via coaxial electrospinning (Invited Paper) [8279-22]

J. P. F. Lagerwall, Seoul National Univ. (Korea, Republic of) and Advanced Institutes of Convergence Technologies (Korea, Republic of)

8279 OP Photo-responsive surface topology in chiral nematic media (Invited Paper) [8279-24] D. Liu, C. W. M. Bastiaansen, J. M. J. Toonder, D. J. Broer, Eindhoven Univ. of Technology (Netherlands) 
$82790 Q \quad$ The activated morphology of grain boundaries in nematic solid sheets (Invited Paper) [8279-25]

C. D. Modes, The Rockefeller Univ. (United States); M. Warner, Univ. of Cambridge (United Kingdom)

\section{NONLINEAR OPTICS AND BEAM STEERING DEVICES}

8279 OT Electrical tuning of index-guiding photonic liquid crystal fibers [8279-28]

S. Ertman, A. Siarkowska, M. M. Tefelska, M. S. Chychłowski, Warsaw Univ. of Technology (Poland); D. Pysz, Institute of Electronics Materials Technology (Poland); R. Buczyński, Univ. of Warsaw (Poland); E. Nowinowski-Kruszelnicki, R. Dabrowski, Military Univ. of Technology (Poland); T. R. Woliński, Warsaw Univ. of Technology (Poland)

8279 OU Green digital signage using nanoparticle embedded narrow-gap field sequential TN-LCDs (Invited Paper) [8279-46]

S. Kobayashi, Y. Shiraishi, H. Sawai, N. Toshima, Tokyo Univ. of Science (Japan); M. Okita, HDT Inc. (Japan); K. Takeuchi, H. Takatsu, DIC Corp. (Japan)

\section{BLUE PHASES AND DISPLAYS}

8279 OV Simulation of a cholesteric blue phase in a thin cell: exotic defect structures and their response to an electric field (Invited Paper) [8279-30]

J. Fukuda, National Institute of Advanced Industrial Science and Technology (Japan);

S. Žumer, Univ. of Ljubljana (Slovenia) and Jožef Stefan Institute (Slovenia)

8279 OW Novel materials for polymer-stabilized blue phase (Invited Paper) [8279-31]

M. Wittek, N. Tanaka, M. Bremer, D. Wilkes, D. Pauluth, K. Tarumi, Merck KGaA (Germany)

\section{LIQUID CRYSTAL ALIGNMENT}

827911 Photoalignment and photopatterning in liquid crystal photonics (Invited Paper) [8279-36]

V. G. Chigrinov, Hong Kong Univ. of Science and Technology (Hong Kong, China)

827912 Controlling the alignment of liquid crystals by nanoparticle-doped and UV-treated polyimide alignment films (Invited Paper) [8279-37]

S.-C. Jeng, National Chiao Tung Univ. (Taiwan); S.-J. Hwang, National United Univ. (Taiwan); T.-A. Chen, H.-S. Liu, M.-Z. Chen, National Chiao Tung Univ. (Taiwan)

827913 New developments in nanoparticle-liquid crystal composites: from magic-sized semiconductor nanoclusters to alignment pattern formation via nanoparticle stenciling (Invited Paper) [8279-38]

J. Mirzaei, R. Sawatzky, Univ. of Manitoba (Canada); A. Sharma, Univ. of Manitoba (Canada) and Kent State Univ. (United States); M. Urbanski, Univ. Paderborn (Germany);

K. Yu, National Research Council Canada (Canada); H.-S. Kitzerow, Univ. Paderborn

(Germany); T. Hegmann, Univ. of Manitoba (Canada) and Kent State Univ. (United States) 
827915 Synthesis and mesomorphism of new 2-methoxy-3-cyanopyridine mesogens [8279-40] T. N. Ahipa, A. V. Adhikari, National Institute of Technology, Karnataka (India)

827917 Characterization of a PDLC mixed with crystal violet dye [8279-42]

J. F. Villa-Manríquez, M. Ortiz-Gutiérrez, Univ. Michoacana de San Nicolás de Hidalgo (Mexico); M. Pérez-Cortés, Univ. Autónoma de Yucatán (Mexico); J. C. Ibarra-Torres, Univ. de Guadalajara (Mexico); A. Olivares-Pérez, M. J. Ordoñez-Padilla, Instituto Nacional de Astrofísica, Óptica y Electrónica (Mexico)

827918 Tunable optical filter based on nanocomposite (liquid crystal)/(porous silicon) [8279-43] G. V. Tkachenko, Kharkov National Univ. of Radio Electronics (Ukraine); I. A. Sukhoivanov, Univ. of Guanajuato (Mexico); O. V. Shulika, Kharkov National Univ. of Radio Electronics (Ukraine); V. Tkachenko, Univ. degli Studi di Napoli Federico II (Italy)

827919 Pretile angle control of liquid crystal from homogeneous to homeotropic using photocurable prepolymer [8279-44]

J.-H. Lee, D. Kang, Soongsil Univ. (Korea, Republic of)

Author Index 


\title{
Conference Committee
}

\author{
Symposium Chair
}

Klaus P. Streubel, OSRAM GmbH (Germany)

Symposium Cochairs

David L. Andrews, University of East Anglia Norwich (United Kingdom) Liang-Chy Chien, Kent State University (United States)

Program Track Chair

Liang-Chy Chien, Kent State University (United States)

Conference Chair

Liang-Chy Chien, Kent State University (United States)

Conference Cochair

Dirk J. Broer, Technische Universiteit Eindhoven (Netherlands)

Program Committee

Vladimir G. Chigrinov, Hong Kong University of Science and Technology (Hong Kong, China)

Harry J. Coles, University of Cambridge (United Kingdom)

Gregory P. Crawford, University of Notre Dame (United States)

Andy Y. Fuh, National Cheng Kung University (Taiwan)

Otto W. Haase, Technische Universität Darmstadt (Germany)

Jun-ichi Hanna, Tokyo Institute of Technology (Japan)

Hirotsugu Kikuchi, Kyushu University (Japan)

Heinz-Siegfried Kitzerow, Universität Paderborn (Germany)

Shunsuke Kobayashi, Tokyo University of Science (Japan)

Seung Hee Lee, Chonbuk National University (Korea, Republic of)

Xiangtong Li, Oplink Communications, Inc. (United States)

Antonio Martins Figueiredo Neto, Universidade de São Paulo (Brazil)

Kristiaan Neyts, Universiteit Gent (Belgium)

Masanori Ozaki, Osaka University (Japan)

Ci-Ling Pan, National Tsing Hua University (Taiwan)

Ryo Sakurai, Bridgestone Corporation (Japan)

Ivan I. Smalyukh, University of Colorado at Boulder (United States)

Richard L. Sutherland, Mount Vernon Nazarene University (United States) 
Shin-Tson Wu, CREOL, The College of Optics and Photonics, University of Central Florida (United States)

Hiroshi Yokoyama, Kent State University (United States)

Tae-Hoon Yoon, Pusan National University (Korea, Republic of)

Ming Hsien Wu, Hamamatsu Corporation (United States)

\section{Session Chairs}

1 New Materials and Effects

Dick J. Broer, Technische Universiteit Eindhoven (Netherlands)

2 Photonic Crystals

Ivan Smalyukh, University of Colorado at Boulder (United States)

3 Lasers

Anders Kristensen, Technical University of Denmark (Denmark)

$4 \quad$ Polarizers and Spatial Light Modulators

Michael J. Escuti, North Carolina State University (United States)

5 Semiconductors

Dirk J. Broer, Technische Universiteit Eindhoven (Netherlands)

6 Tunable Filters

Vincent Tondiglia, SAIC (United States)

$7 \quad$ Actuators and Sensors

Myong-Hoon Lee, Chonbuk National University (Korea, Republic of)

$8 \quad$ Nonlinear Optics and Beam Steering Devices

Vladimir Chigrinov, Hong Kong University of Science and Technology (Hong Kong, China)

9 Blue Phases and Displays

Jan P. F. Lagerwall, Martin-Luther Universität Halle-Wittenberg (Germany)

10 Self-assembly of Photonic Materials

Oleg D. Lavrentovich, Kent State University (United States)

11 Liquid Crystal Alignment

Tae-Hoon Yoon, Pusan National University (Korea, Republic of) 